Article

\title{
Characterization of Soluble Sugar Content, Related Enzyme Activity and Gene Expression in the Fruits of 'Minihyang' Mandarin on Different Rootstocks
}

\author{
Ha Rim Hong ${ }^{1}{ }^{(D)}$, Eun Ui Oh ${ }^{1}$, Seung Gab Han ${ }^{2}$, Su Hyun Yun ${ }^{2}$, Ho Bang Kim ${ }^{3}$ and Kwan Jeong Song ${ }^{1,4, *}$ \\ 1 Department of Horticultural Science, Jeju National Universtiy, Jeju 63243, Korea; \\ gkfla1206@naver.com (H.R.H.); aaa3056@naver.com (E.U.O.) \\ 2 Citrus Research Institute, National Institute of Horticultural \& Herbal Science, RDA, Jeju 63607, Korea; \\ skhan@korea.kr (S.G.H.); yunsh04@korea.kr (S.H.Y.) \\ 3 Life Sciences Research Institute, Biomedic Co., Ltd., Bucheon 14548, Korea; hobang@ibiomedic.co.kr \\ 4 Research Institute for Subtropical Agriculture \& Biotechnology, Jeju National Universtiy, Jeju 63243, Korea \\ * Correspondence: kwansong@jejunu.ac.kr; Tel.: +82-64-754-3328
}

\section{check for}

updates

Citation: Hong, H.R.; Oh, E.U.;

Han, S.G.; Yun, S.H.; Kim, H.B.;

Song, K.J. Characterization of Soluble Sugar Content, Related Enzyme Activity and Gene Expression in the Fruits of 'Minihyang' Mandarin on Different Rootstocks. Horticulturae 2022, 8, 47. https://doi.org/10.3390/ horticulturae 8010047

\section{Academic Editor: Stefano}

Giovanni La Malfa

Received: 14 December 2021

Accepted: 1 January 2022

Published: 4 January 2022

Publisher's Note: MDPI stays neutral with regard to jurisdictional claims in published maps and institutional affiliations.

Copyright: (c) 2022 by the authors. Licensee MDPI, Basel, Switzerland. This article is an open access article distributed under the terms and conditions of the Creative Commons Attribution (CC BY) license (https:// creativecommons.org/licenses/by/ $4.0 /)$.

\begin{abstract}
Minihyang' mandarin bears fruits with small size and high sugar content. 'Minihyang' mandarin grafted on trifoliate orange (TO) tends to be vigorous and develops water sprout open. It is associated with insufficient floral differentiation and fruit set. Recently, the use of Flying Dragon (FD) as rootstock with a high dwarf effect has been proposed to improve this situation. Therefore, this study was conducted to evaluate the effect of two different rootstock genotypes on tree growth, fruit yield, and fruit quality at the physiological, biochemical, and molecular levels. As a result of the study, in FD, tree vigor was stably maintained, fruit size was large, and the sugar content was high compared to the TO. Fructose, glucose, and sucrose of fruit continued to increase from development to maturity. In particular, fructose and sucrose were significantly higher in the fruits of the FD than those in TO at 150 and 220 days after anthesis. The total sugar content was also significantly higher in the fruit of the FD. The activities of SPS and SS associated with sucrose synthesis tended to be increased during the fruit maturity season, but there was no significant difference between the two rootstocks. On the other hand, the activities of SS and AI breaking down sucrose were high in FD at 150 and 220 days after anthesis. These results suggest that the unloading of sucrose might be increased and affect the sugar content. However, the results of real-time PCR analysis of gene expression related to sucrose metabolism did not show an association with changes in enzyme activity affecting sugar content. Therefore, further detailed studies on the process after the regulation of gene expression are likely to be needed.
\end{abstract}

Keywords: citrus; Flying Dragon; fruit quality; sucrose metabolism; trifoliate orange

\section{Introduction}

The citrus is one of the most important fruit crops in Korea and the world. Citrus fruits contain various nutrients, such as vitamin C, minerals, flavonoids, and fiber, playing a crucial role in improving health and preventing chronic diseases [1]. Especially, it accounts for about $32 \%$ of the total fruit production, which ranks first among the fruits in Korea [2]. The fruit growing is generally performed with scion, fruiting part and rootstock, underground part. These two parts consist of two different cultivars, and then rootstock significantly affects scion tree performance such as canopy size, fruit set, and fruit quality [3,4]. The trifoliate orange (Poncirus trifoliata (L.) Raf.) (TO) is most commonly used as the rootstock of citrus in Korea because of its high tolerance to cold, acidic soil, citrus tristeza virus and phytophthora disease, and induction of semi-dwarfism of scion part [5].

'Minihyang' mandarin is a hybrid ('Kinokuni' $\times$ 'Ponkan' mandarin) bred at the Citrus Research Institute, the National Horticultural and Herbal Science, in Korea. Its 
growth has been recently expanded due to bearing the fruits with high sweetness ( $13^{\circ} \mathrm{Brix}$ ) even though small size (30-40 g). However, it is not easy to manage the canopy for floral differentiation securing economic fruit set because scion trees become too vigorous when TO is used as a rootstock. Then Korean citrus industry needs cultural trials on the rootstocks being much more dwarf than TO. It has been reported that the cultural performance of Frying Dragon trifoliate orange (Poncirus trifoliata var. monstrosa Swing.) (FD) is very similar to TO in most traits except for being much dwarf [6], which is never evaluated in 'Minihyang' mandarin, yet.

The difference of sugar content and composition in citrus was associated with the rootstock genotypes $[7,8]$, which might be attributed to the degree of sucrose metabolismrelated enzyme activities and gene expression. The sucrose metabolism is controlled by sucrose synthesis and cleavage mechanism [9]. It is known that sucrose phosphate synthase (SPS) and sucrose synthase (SS) are involved in the synthesis of sucrose [10], and SS and invertase (IV) are involved in the cleavage of sucrose [11]. Therefore, there is a possibility that the activity of these enzymes may vary depending on the type of rootstock. In addition, their activity changes may be related to transcription, translation, and post-translational modification mechanisms of genes encoding these enzymes. In pineapple, it was also reported that the expression of SPS, SS, and neutral invertase (NI) genes showed distinct patterns associated with sugar accumulation and composition at the different developmental stages of pineapple fruits [12]. However, there are few such studies in citrus so far.

Therefore, this study was conducted to evaluate the effect of the rootstock on the sugar content of 'Minihyang' citrus fruits and scion tree growth and yield and to analyze the relationship between the sucrose metabolism enzyme activity and gene expression patterns.

\section{Materials and Methods}

\subsection{Plant Materials}

Four-year-old 'Minihyang' mandarin (Citrus reticulate Blanco) grafted on TO and FD were used in this study. These trees were planted at the distance of $2 \times 2.9 \mathrm{~m}$ in the unheated plastic house located at the Citrus Research Institute ( $\left.33^{\circ} 18^{\prime} 8.74^{\prime \prime} \mathrm{N}, 126^{\circ} 36^{\prime} 43^{\prime \prime} \mathrm{E}\right)$, Jeju, Korea. All trees were managed by conventional cultural practices. Biological replicate consists of three trees selected randomly.

\subsection{Measurement of Scion Tree Growth, Yield, and Fruit Quality Characteristics}

Tree height and width, the mean length and thickness of one-year-old shoots, the mean number and length of thorns developed in one-year-old shoots, and the total number and mean length of water sprouts were measured in the winter season, in which annual growth finished. The yield was evaluated with the total number of fruit-bearing and the mean fruit weight at harvest. Fruit growth, including fruit weight, size and shape, and fruit quality, including soluble solids content (SSC), titratable acidity (TA), and rind coloration, were measured 100, 150, 185, and 220 days after anthesis. Three fruits were randomly selected per tree and used to evaluate fruit growth and quality. The SSC and TA of squeezed fruit juice were measured with a digital sugar and acid analyzer (GMK-707R, G-won Hitech Ltd., Daegu, Korea), and the rind coloration was measured using a colorimeter (CR-400 Chroma Meter, Konica Minolta Inc., Tokyo, Japan).

\subsection{Fruit Sugar Analysis}

Three fruits per tree were randomly collected for sugar analysis. The peel and segment epidermis of fruits were quickly separated, and only the juice sacs were immediately frozen using liquid nitrogen. They were stored at $-80{ }^{\circ} \mathrm{C}$ before using to analyze juice sugar content, related enzyme activities, and gene expression.

For the analysis of juice sugar content, the frozen juice sacs were slowly thawed and were squeezed with a two-layer cheesecloth. The juice extract was diluted three times with distilled water and centrifuged at 10,000 rpm for $10 \mathrm{~min}$. The supernatant was passed through Sep-Pak 
C18 cartridges (Waters Co., Milford, MA, USA) and filtered using a $0.45 \mu \mathrm{m}$ syringe filter (Cytiva, Co., Maidstone, UK). Then soluble sugar (fructose, glucose, and sucrose) content was determined with HPLC (LC-20AT, Shimadzu, Inc., Kyoto, Japan) equipped with ZORBAX $\mathrm{NH} 2$ column $(4.6 \times 250 \mathrm{~mm}, 5 \mu \mathrm{m}$, Agilent Technologies, Inc., Santa Clara, CA, USA $)$ and conditioned with a mobile phase [acetonitrile: water $=80: 20(v / v)], 20 \mu \mathrm{L}$ sample volume, $1 \mathrm{~mL} \cdot \mathrm{min}^{-1}$ flow rate, and $35{ }^{\circ} \mathrm{C}$ column temperature.

\subsection{Enzyme Extraction and Assay}

The extraction of sucrose metabolic enzymes was followed by the Kubo method with some modifications [13]. Four grams of frozen juice sacs were homogenized in a prechilled mortar and pestle with $10 \mathrm{~mL}$ of a buffer solution [0.5 M hydroxyethyl piperazine ethane sulfonic acid (Hepes)-KOH (pH 7.5), $1 \mathrm{mM}$ ethylene-diamine-tetraacetic acid (EDTA), $5 \mathrm{mM}$ $\mathrm{MgCl}_{2}, 150 \mathrm{mM} \mathrm{NaCl}, 5 \mathrm{mM}$ 1,4-dithiothreitol (DTT), $1 \mathrm{mM}$ phenylmethylsulfonyl fluoride (PMSF), $1 \mathrm{mM} \mathrm{CaCl}_{2}$ and $2 \%(v / v)$ glycerol]. The resulting mixture was centrifuged for $10 \mathrm{~min}$ at $12,000 \times \mathrm{g}$. After loading $2.5 \mathrm{~mL}$ of supernatant in the Sephadex PD-10 column (Amersham Pharmacia Biotech, Inc., Piscataway, NJ, USA) pretreated with a desalting buffer [20 mM Hepes- $\mathrm{KOH}$ (pH 7.2), $10 \mathrm{mM} \mathrm{MgCl} 2,5 \mathrm{mM} \beta$-mercaptoethanol, and $10 \%$ $(v / v)$ glycerol], $3.5 \mathrm{~mL}$ was collected and used as a crude enzyme extract.

The activities of SS and SPS were determined by the method of Song with some modifications [14]. The sucrose synthesis activity of SS was determined using the mixture of $100 \mathrm{mM}$ Hepes- $\mathrm{KOH}$ ( $\mathrm{pH} 7.2), 5 \mathrm{mM} \mathrm{MgCl}_{2}, 2 \mathrm{mM}$ uridine diphosphate glucose (UDPG), $10 \mathrm{mM}$ fructose, and crude enzyme extract. Whereas the sucrose cleavage activity of SS was measured using the mixture of $20 \mathrm{mM}$ Hepes- $\mathrm{KOH}$ (pH 7.2), $4 \mathrm{mM}$ uridine diphosphate (UDP), $10 \mathrm{mM}$ sucrose, and crude enzyme extract. SPS activity was determined using mixture of $61.7 \mathrm{mM}$ Hepes-KOH (pH 7.5), $19.2 \mathrm{mM} \mathrm{MgCl}$, $1.3 \mathrm{mM}$ EDTA, $7.7 \mathrm{mM}$ UDPG, $9 \mathrm{mM}$ fructose 6-phosphate (F-6-P), $49.5 \mathrm{mM}$ glucose 6-phosphate (G-6-P), and crude enzyme extract. The sucrose synthesis activities of SS and SPS were assayed at $10 \mathrm{~min}$ intervals for $30 \mathrm{~min}$, and the sucrose cleavage activity of SS was assayed at $30 \mathrm{~min}$ intervals for $90 \mathrm{~min}$ with boiling at $100{ }^{\circ} \mathrm{C}$ for $3 \mathrm{~min}$ to terminate the reaction. All reactions were carried out at $30^{\circ} \mathrm{C}$. AI activity was determined by Kubo with a modification [13] in the mixture of $103 \mathrm{mM}$ Na-acetate ( $\mathrm{pH}$ 5.2), $10 \mathrm{mM}$ sucrose, and crude enzyme extract. The assays were conducted at $30 \mathrm{~min}$ intervals for $90 \mathrm{~min}$, at $37^{\circ} \mathrm{C}$ with boiling at $100{ }^{\circ} \mathrm{C}$ for $3 \mathrm{~min}$ to terminate the reaction. The sucrose produced or broken down by each enzyme during assay was measured by the anthrone method [15]. The total protein concentration of crude enzyme extracts was measured at $595 \mathrm{~nm}$ using a Bio-Rad protein assay kit (Bio-Rad 500-0001, Bio-Rad Laboratories, Inc., Hercules, CA, USA) by the Bradford method [16].

\subsection{Quantitative Real-Time ( $q R T)$-PCR Reaction Analysis}

For total RNA extraction, juice sac tissue was homogenized in a prechilled mortar and pestle with quartz sand and polyvinylpolypyrrolidone (PVPP) using liquid nitrogen. Total RNA was extracted using the Biomedic ${ }^{\circledR}$ RNAxzol ${ }^{\mathrm{TM}}$ kit (Biomedic Co., Ltd., Bucheon, Korea) according to the manufacturer's instructions. Quantitative and qualitative analysis of the extracted RNA was conducted using a spectrophotometer (DeNovix DS-11+, DeNovix, Inc., Wilmington, DE, USA) and 1.2\% ( $v / v)$ agarose gel electrophoresis. cDNA was synthesized with a PrimeScript ${ }^{\mathrm{TM}} \mathrm{RT}$ reagent kit (TaKaRa, Inc., Kusatsu, Japan). The primers for CitSPS1, CitSPS2, CitSUS, CSCW1, CitAI, and NIN were designed with the information of Dong [7]. The qRT-PCR was performed with three biological replicates and two technical replicates in a $20 \mu \mathrm{L}$ mixture volume of $4 \mu \mathrm{L}$ cDNA, $0.8 \mu \mathrm{L}$ forward and reverse gene-specific primers (each $10 \mathrm{pmol} \cdot \mu \mathrm{L}^{-1}$ ), $10 \mu \mathrm{L}$ TOPreal qPCR $2 \times$ premix (Enzynomics, Inc., Daejeon, Korea) and $5.2 \mu \mathrm{L}$ sterile distilled water using the LightCycler ${ }^{\circledR}$ 480 II real-time PCR system (Roche Diagnostics GmbH, Co, Ltd., Mannheim, Germany). The reaction of qRT-PCR was started with an initial denaturation at $95{ }^{\circ} \mathrm{C}$ for $5 \mathrm{~min}$ and followed by 45 cycles of $15 \mathrm{sec}$ at $95^{\circ} \mathrm{C}, 20 \mathrm{sec}$ at $60^{\circ} \mathrm{C}$, and $30 \mathrm{sec}$ at $72{ }^{\circ} \mathrm{C}$. The relative 
gene expression was analyzed using the composite $C_{T}$ method by calculating a value of 2-(Ct target gene-Ct housekeeping gene).

\subsection{Statistical Analysis}

Data were presented as means \pm standard errors. Statistical significance was analyzed using the SPSS 18.0 software (SPSS, Inc., Chicago, IL, USA) at $p<0.05$.

\section{Results and Discussion}

\subsection{Effect of Different Rootstocks on Scion Tree Vegetative Growth, Yield, and Fruit Quality}

The vegetative growth characteristics of the 'Minihyang' mandarin grafted on two different rootstocks are represented in Table 1. The tree height of 4-year-old 'Minihyang' mandarin grafted on FD was $1.4 \mathrm{~m}$, whereas that grafted on the TO was $4.0 \mathrm{~m}$, which had a difference of about three times. The large canopy of scion grafted on TO was attributed to the strong development of shoots including water sprouts. Therefore, the result indicated that TO induced the scion to be much vigorous than FD. These results were in accord with the previous studies $[6,8,17,18]$, which reported smaller scion height or canopy with the low development of shoots and thorns at the different levels depending on scion cultivars grafted on FD compared to TO.

Table 1. Tree vegetative growth of 'Minihyang' mandarin grafted on trifoliate orange (TO) and Flying Dragon (FD) rootstocks.

\begin{tabular}{|c|c|c|c|c|c|c|c|c|}
\hline \multirow{2}{*}{ Rootstock } & \multicolumn{2}{|c|}{ Tree Size } & \multicolumn{4}{|c|}{ One-Year-Old Shoots } & \multicolumn{2}{|c|}{ Water Sprout } \\
\hline & $\begin{array}{l}\text { Height } \\
\text { (m) }\end{array}$ & $\begin{array}{l}\text { Width } \\
\text { (m) }\end{array}$ & $\begin{array}{l}\text { Length } \\
\text { (cm) }\end{array}$ & $\begin{array}{l}\text { Thickness } \\
\text { (mm) }\end{array}$ & $\begin{array}{l}\text { No. of } \\
\text { Thorn }\end{array}$ & $\begin{array}{l}\text { Thorn Length } \\
\text { (cm) }\end{array}$ & Number & $\begin{array}{l}\text { Length } \\
\text { (cm) }\end{array}$ \\
\hline TO & $4.0 \pm 0.1$ & $1.5 \pm 0.1$ & $24.8 \pm 0.7$ & $2.99 \pm 0.05$ & $8.5 \pm 0.4$ & $1.5 \pm 0.1$ & $25.0 \pm 3.3$ & $221.1 \pm 4.8$ \\
\hline FD & $1.4 \pm 0.2$ & $0.7 \pm 0.1$ & $9.8 \pm 0.9$ & $2.15 \pm 0.11$ & $1.2 \pm 0.3$ & $0.5 \pm 0.0$ & $10.5 \pm 0.5$ & $81.8 \pm 15.8$ \\
\hline Significance & * & * & * & * & * & $*$ & * & * \\
\hline
\end{tabular}

* Mean separation within columns by T-test at $5 \%$ level.

The number of fruit-bearing per tree in TO was higher than in FD due to large canopy formation (Table 2). However, despite the higher fruit-bearing per tree, the yield on TO was much lower than that on FD $\left(1.3 \mathrm{~kg} \cdot \mathrm{m}^{-2}\right.$ and $5.7 \mathrm{~kg} \cdot \mathrm{m}^{-2}$ on TO and FD, respectively), which was four times lower due to small fruit size, light fruit weight and low fruit-bearing per unit area. The result was quite different from the previous studies reporting that larger fruit size and higher yield were obtained in Satsuma mandarin grafted on TO than FD [6,8,17-19]. However, Mademba-Sy reported that the fruit size affected by FD was considerably different depending on citrus species [6]. Therefore, the result also indicated that the yield and fruit size affected by FD might differ depending on citrus genotypes. On the other hand, the difference in fruit size was tiny at the initial stage of fruit enlargement but became significantly larger as fruit matured through cell enlargement with slight changes of fruit shape represented by the L/D ratio (Figure 1b). Especially at the initial stage of fruit enlargement, there was only a difference in fruit length among fruit size parameters (Figure 1a). Final fruit size is determined during the cell division phase of early fruit growth [20], and the cell number of fruit is closely associated with carbohydrate partitioning and availability [21]. In citrus, the elevated temperature at the early fruit developmental stage promoted the longitudinal growth much higher than diametral growth, which was associated with larger and heavier fruits [22]. Therefore, the result indicated that larger fruits on FD might be attributed to strong sink strength at the fruit enlargement and maturity stages the early fruit growth stage. 
Table 2. Yield of 'Minihyang' mandarin grafted on trifoliate orange (TO) and Flying Dragon (FD) rootstocks at harvest.

\begin{tabular}{|c|c|c|c|}
\hline Rootstock & Number of Fruits Per Tree & Fresh Weight (g) & Yield $\left(\mathrm{kg} \cdot \mathrm{m}^{-2}\right)$ \\
\hline $\mathrm{TO}$ & $426 \pm 51.7$ & $46.5 \pm 2.5$ & $1.3 \pm 0.2$ \\
\hline FD & $183 \pm 47.0$ & $61.8 \pm 2.8$ & $5.7 \pm 0.8$ \\
\hline Significance & * & * & * \\
\hline
\end{tabular}

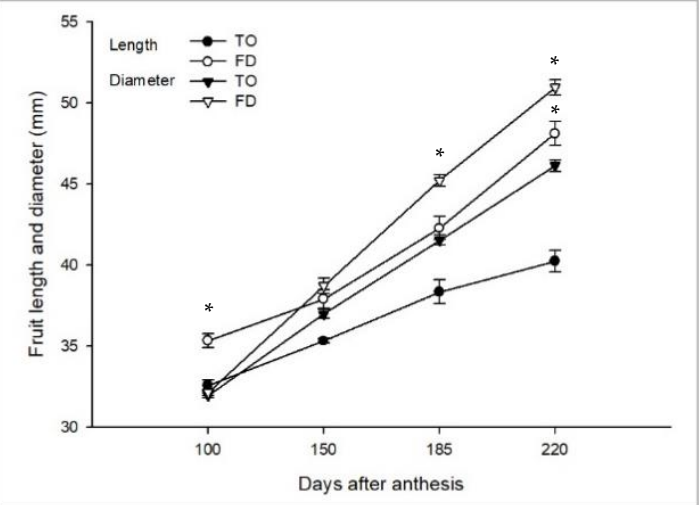

(a)

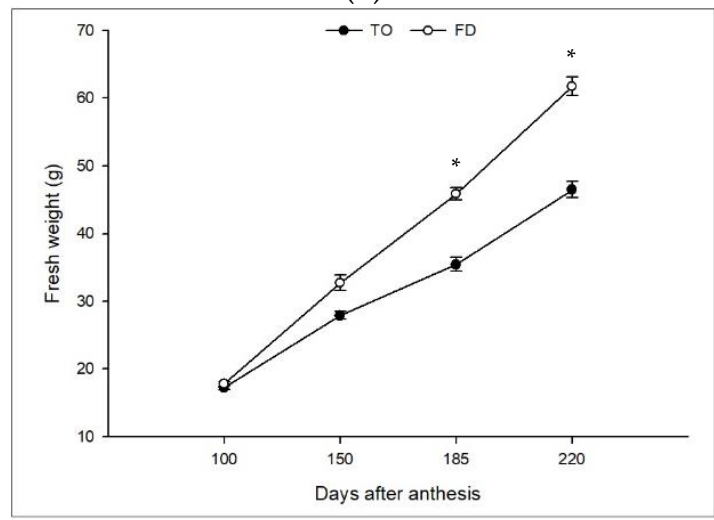

(c)

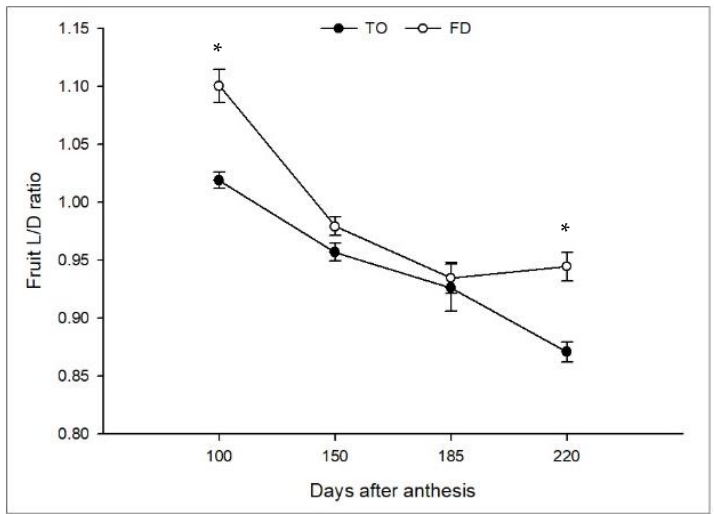

(b)

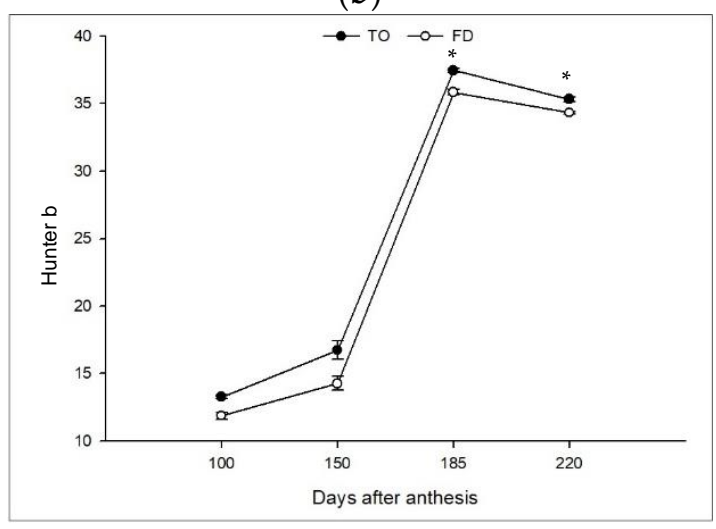

(d)

Figure 1. Changes of fruit length (L) and diameter (D) (a), L/D ratio (b), fruit weight (c) and rind coloration (d) during the fruit development in 'Minihyang' mandarin grafted on trifoliate orange (TO) and Frying Dragon (FD) rootstocks. * Mean separation within columns by T-test at $5 \%$ level.

The rootstocks affected the SSC and TA of fruits in 'Minihyang' mandarin. FD represented higher SSC than TO with a range of 0.6-1.1 ${ }^{\circ}$ Brix during all fruit developmental stages (Figure 2). However, TA represented some different patterns to SSC despite higher TA on FD during all fruit developmental stages, and there was little difference except an apparent difference with $1.1 \%$ at an initial enlargement stage. Rind coloration was not affected by two different rootstock genotypes of TO and FD (Figure 1d). Several studies have already reported that FD enhanced fruit quality with higher SSC and similar TA than those of TO in Satsuma mandarin $[8,17,18]$ and sweet orange [19], which was consistent with the results of this present study. On the other hand, Cantuarias-Avilés and Bowman suggested that the effect of FD on higher TSS may be associated with water stress induced by FD, but it remained to be elucidated in the future $[17,23]$. 


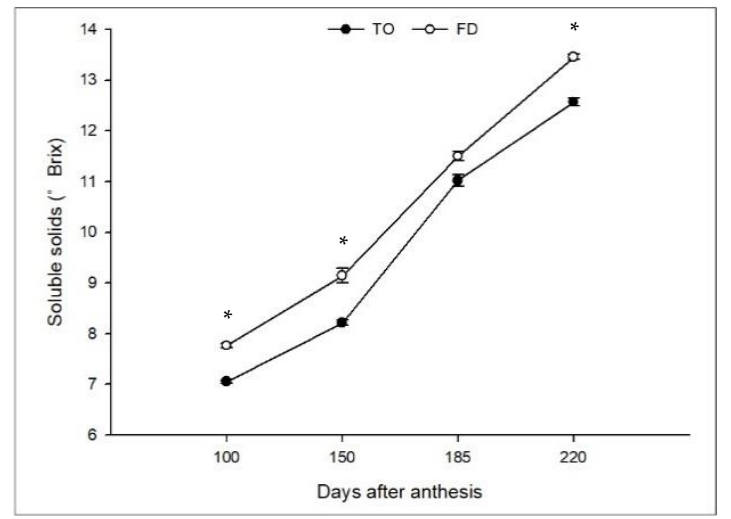

(a)

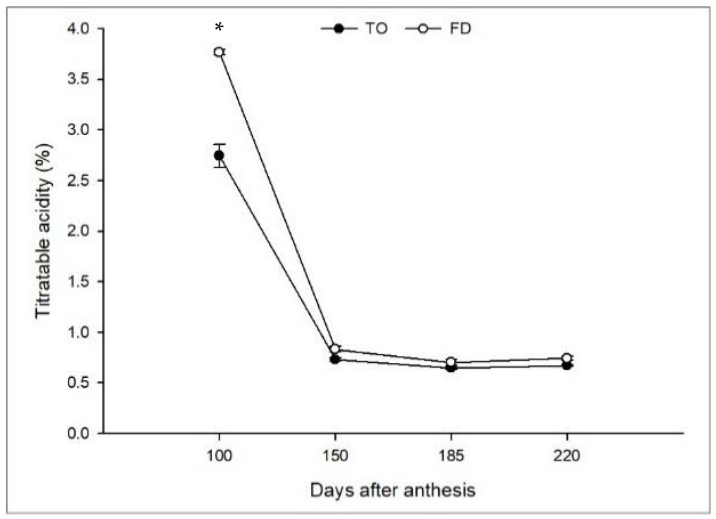

(b)

Figure 2. Change of soluble solids (a) and titratable acidity (b) in 'Minihyang' fruits grafted on trifoliate orange (TO) and Frying Dragon (FD) rootstocks. * Mean separation within columns by T-test at $5 \%$ level.

\subsection{Effect of Different Rootstocks on Sugar Contents}

The soluble sugar contents of fruits were analyzed during fruit development in 'Minihyang' mandarins grafted on TO and FD (Figure 3). The total sugar content was rapidly increased during the fruit enlargement and early maturity stage and gradually during the late maturity stage. The major component of soluble sugars was sucrose, which accounted for about a half in the fruit enlargement stage and most at harvest. All individual sugar was higher in the fruits from FD than those from TO. However, significant differences were recognized in fructose, sucrose and, total sugar except for glucose. The results indicated that soluble sugar contents were affected by the rootstock genotype. Although the pattern of increase in total sugar content and the difference of level affected by rootstock were similar to those in SSC, there were some differences at the early fruit enlargement and late maturity stages. There was no difference in total sugar content between the two rootstocks at the early fruit enlargement stage, whereas SSC showed a significant difference between the two rootstocks. At the late maturity stage, the increased level was higher in SSC than total sugar content. The ratio of total sugar content to SSC was continuously increased during all fruit developmental stages.

In citrus fruits, the primary component of soluble sugars was sucrose, but the composition of soluble sugars differed depending on species and cultivars [14,21,24,25]. Therefore, it might be attributed to a genotypic characteristic that the sucrose was a majority of soluble sugars in 'Minihyang' mandarin. It was reported that the content of sucrose and fructose of 'Kiyomi' fruits at the late developmental stage significantly differed in two different rootstocks, while the content of glucose was not significantly different [7], which was consistent with the results of this study. On the other hand, Raddatz-Mota reported no significant difference in the sugar contents and composition of the fruit among rootstocks despite great variation [26]. The sugar contents of scion fruits might be very diverse depending on a combination of scion and rootstock genotypes because rootstocks modify the water potential and nutrient levels of scion cultivars [27], which affects sugar contents [28,29]. Therefore, the result of sugar contents and composition from the present study might be attributed to the specific response of 'Minihyang' mandarin by different rootstocks. 


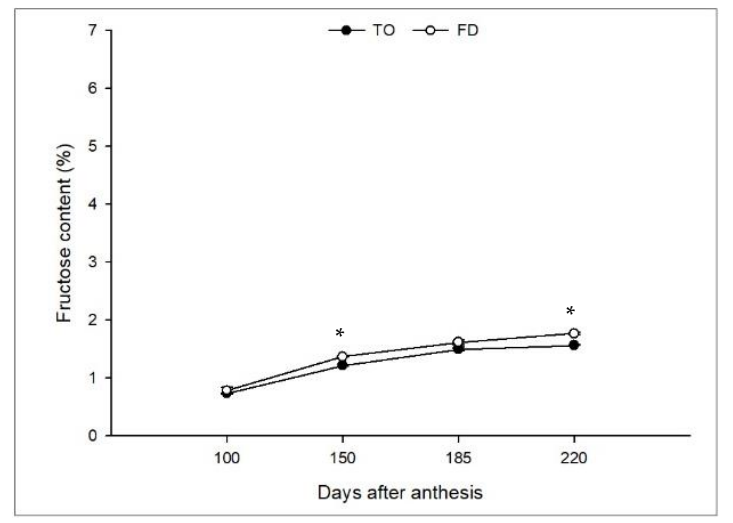

(a)

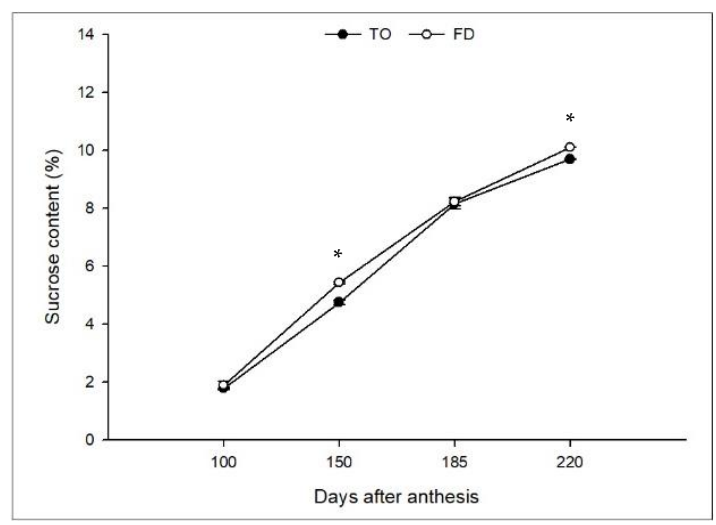

(c)

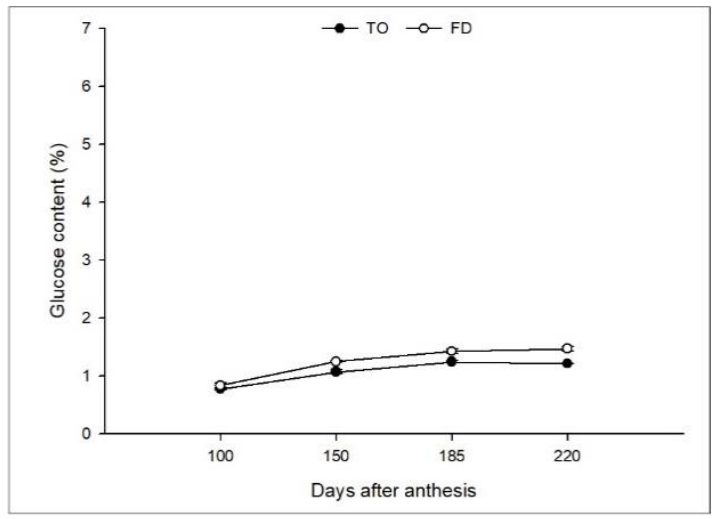

(b)

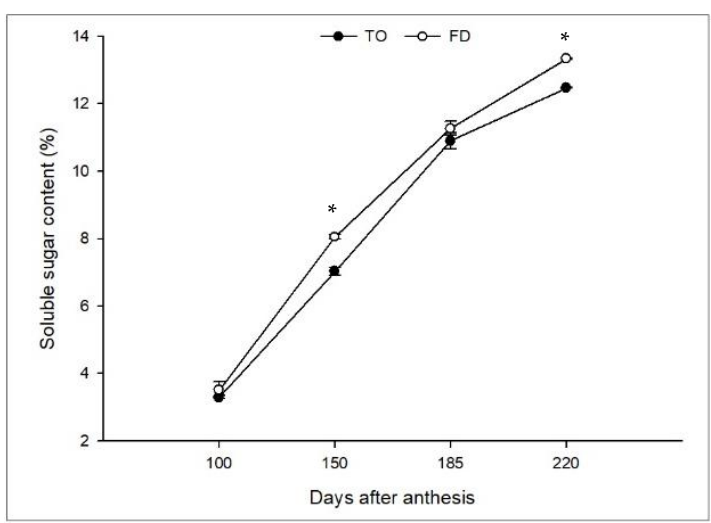

(d)

Figure 3. Soluble sugar contents in the fruits of 'Minihyang' mandarin grafted on different rootstocks. (a) fructose; (b) glucose; (c) sucrose; (d) total soluble sugars. * Mean separation within columns by T-test at $5 \%$ level.

\subsection{Effect of Different Rootstocks on Sucrose Metabolic Enzyme Activities}

The sugar contents of fruits are the outcome of sugar metabolism controlled by sugar metabolic enzyme activities [1,30]. Then the activities of significant sucrose metabolic enzymes including, SPS, SS, AI and, NI, were evaluated during the fruit development of 'Minihyang' mandarin grafted on two different rootstocks (Figure 4). The SPS activity remained almost unchanged, with a small fluctuation during the fruit development and a slight decline at the late fruit enlargement stage. There was a tendency of a little higher SPS activities in TO than FD except for at the early maturity stage; however, there was no significance. The SS-synthesis activity had increased by the early fruit maturity stage and then was sharply declined at the late maturity stage. There was a tendency for a little higher SS-synthesis activities in FD than TO except at the early maturity stage; however, there was no significant difference. The SS-cleavage activity was a little different depending on rootstock genotypes. The SS-cleavage activities were high at the early fruit enlargement stage and were declined at the late fruit enlargement stage in both rootstocks. However, thereafter, the SS-cleavage activity was gradually increased a little bit in FD, whereas it was increased and kept at a similar level. During the whole fruit development, the SS-cleavage activity was higher in FD than TO. The activities of AI and NI also differed a little depending on rootstock genotypes as in SS-cleavage activity; the tendency during the fruit development was different, too. The AI had high activity at the early fruit development stages. On the other hand, the NI had high activity at the late fruit development stages with the shift of role each other during the fruit development. 


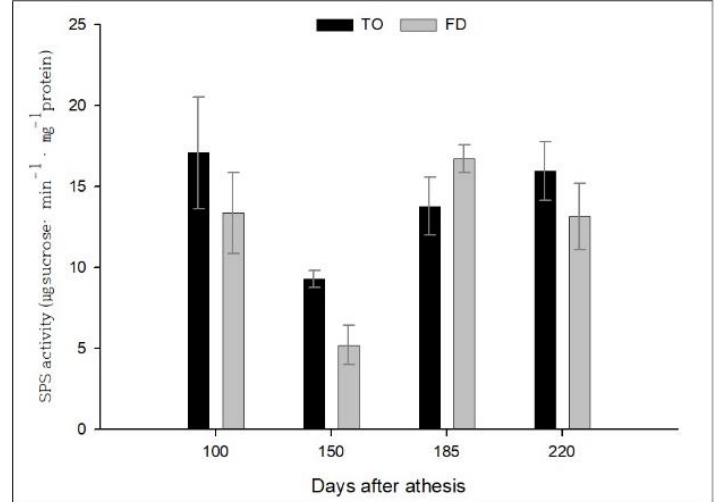

(a)

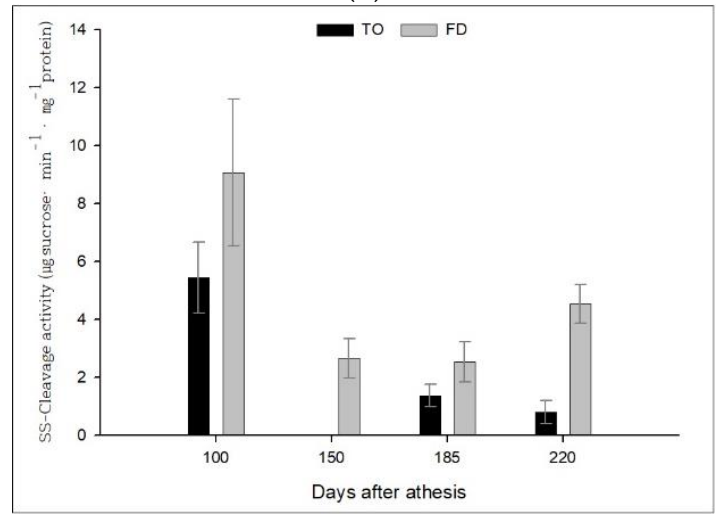

(c)

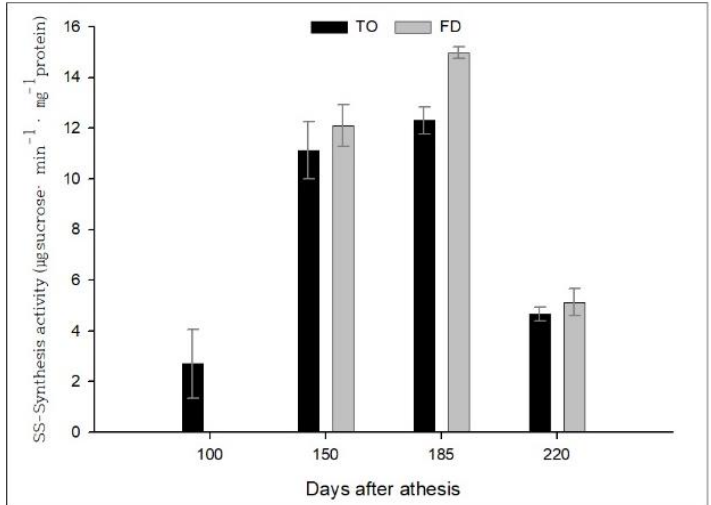

(b)

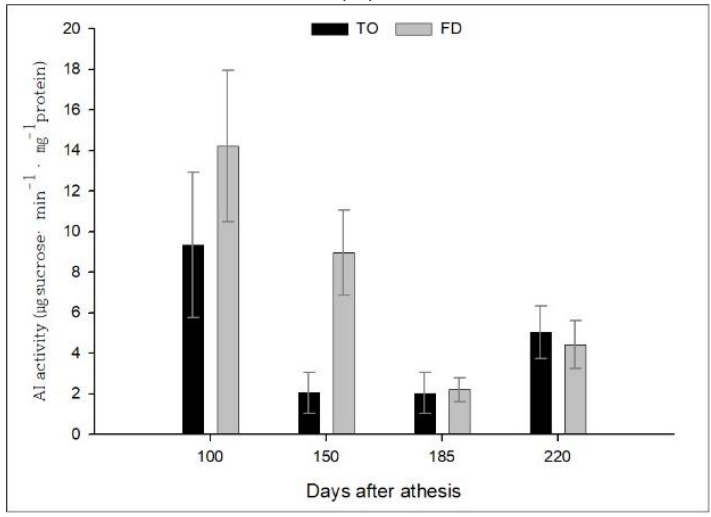

(d)

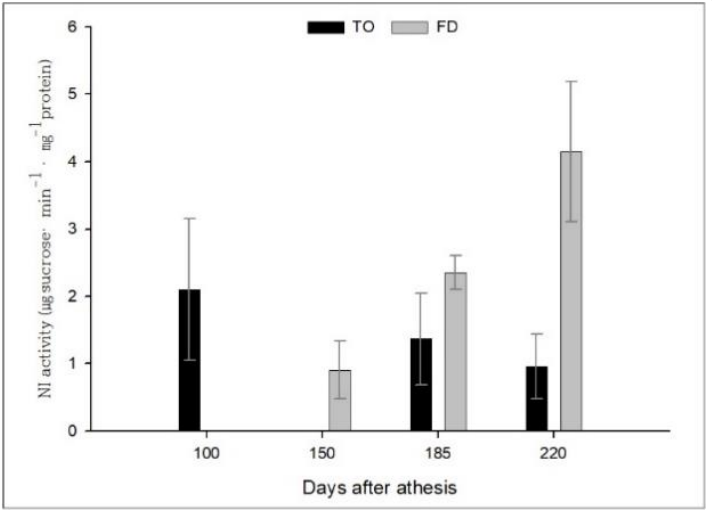

(e)

Figure 4. Sucrose metabolic enzyme activities in the fruit of 'Minihyang' mandarin grafted on different rootstocks. (a) SPS activity; (b) SS-synthetic activity; (c) SS-cleavage activity; (d) AI activity; (e) NI activity.

The sugar content of citrus fruits is determined by the unloading process of sucrose transported from source leaves and sugar accumulation process into sink juice sac tissues [1]. The sucrose unloading process is primarily controlled by sucrose catabolism, which is accompanied by sucrose cleavage enzyme activities such as cleavage-SS, AI, and NI. The sucrose accumulation process is primarily controlled by sucrose anabolism, which is accompanied by sucrose synthesis enzyme activities such as SPS and synthesis-SS. The fruits of 'Minihyang' mandarin showed an increasing pattern in total sugar content, which was mainly accompanied by an increase of sucrose during the fruit development (Figure 3). It corresponded well to the sucrose synthesis potential combined with SPS and synthesis-SS and the sucrose unloading potential combined with cleavage-SS, AI, and NI (Figure 4). Especially, the higher contents of total sugar and sucrose in FD compared to TO were 
consistent with the sucrose unloading potential combined with cleavage-SS, AI, and NI despite no statistical significance in each enzyme activity. Barry suggested that the effect of rootstock on an increase of sugar accumulation was related to osmotic adjustment and sucrose hydrolysis [31], and Hockema indicated that drought-enhanced sugar accumulation was attributed just to an increase of SS-cleavage activity [32]. Therefore, the present study's result indicated that increased sugar accumulation from FD might be attributed to enhanced sucrose unloading potential and sink strength combined with cleavage-SS, AI, and NI.

\subsection{Effect of Different Rootstocks on the Expression of Sucrose Metabolic Enzyme Genes}

Sucrose unloading and accumulation are controlled by the regulation of sugar metabolic enzymes, which are affected by the expression of sugar metabolic enzyme genes through modifying the process of transcription and post-transcription. The present study evaluated quantitative transcription for six genes related representatively to sucrose unloading and sugar accumulation (Figure 5). The CitSPS1 expression was kept constant during fruit development. On the other hand, the CitSPS2 expression was low at the fruit enlargement stage. However, it was expressed at a high level at the fruit maturity stage. The CitSPS1 expression, unlike CitSPS2, was well corresponded to the pattern of SPS activity during the fruit development. However, there was no difference in the expression level between the two rootstocks. The expression of CitSUS encoding cleavage-SS was low at the early fruit enlargement stage and after that was kept constantly at the high level, which was not compatible with the pattern of SS-cleavage activity. The expression of CSCW1 encoding cell wall-bound AI was high at the early fruit enlargement stage. The expression of CitAI encoding AI was low at the early fruit enlargement stage and after that was kept constantly at the high level, which was not compatible with the pattern of AI activity. The expression of NIN encoding NI was low at the early fruit enlargement stage, and after that, was increased gradually during the late fruit development, which was similar to the pattern of NI activity.

Just a few studies have reported the expression of sugar metabolic genes in citrus $[7,24,33]$. Three isoforms of citrus SPS gene (CitSPS1, CitSPS2, and CitSPS3) encoding SPS were separated from the citrus by Komatsu, CitSPS1 and CitSPS2 of which were expressed in the fruits [34]. Komatsu also reported two isoforms of citrus SS gene (CitSuSy1, CitSuSy2, and CitSuSyA), CitSuSy1 of which was greatly involved in the sucrose accumulation of the fruits [34]. Recently, it was reported that the CitSUS1 and CitSUS2 of six SS genes (CitSUS1-6) cloned from sweet orange had specific expression in citrus juice sacs, CitSUS1 of which was the high similarity to CitSuSy1 [33]. Then six genes, including CitSPS1, CitSPS2, CitSUS, CSCW1, CitAI, and NIN, were selected for this study. The results indicated that the expression of these genes did not correspond well to the pattern of those enzyme activities. However, the others were not compatible with the pattern of those enzyme activities (Figures 4 and 5). It was reported that the sugar accumulation at the late fruit maturity stage of the late-ripening orange mutant was attributed to the enhanced sink strength combined with CitAI, CitSUS1, and CitSPS2 [24]. Dong showed that higher sugar accumulation in the fruits of 'Kiyomi' tangor grafted on TO compared to that of yuzu was caused by the significant increase of CitSPS1, CitSPS2, CitSUS, CSCW1, CitAI, and NIN [7], unlike the results of this study. Therefore, the result of this study might imply the existence of posttranscriptional modification with time-lagged regulation. The sugar contents of fruits were determined by comprehensive outcome regulated with diverse metabolic factors, including sucrose unloading and sugar compartmentation and, organic acid and amino acid metabolism [1]. Depending on scion genotypes, rootstock genotypes and the growing environment, these diverse metabolic factors might respond differently. Consequently, a further integrated study is necessary to interpret the responses caused by interaction between scion and rootstock genotypes. 


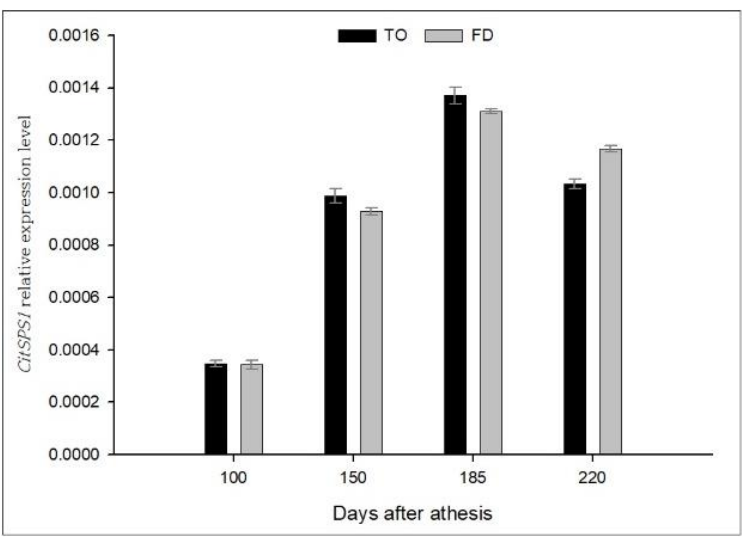

(a)

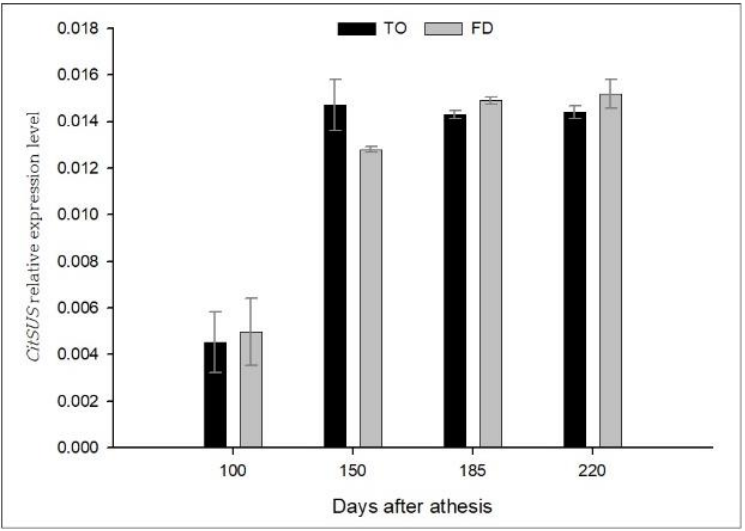

(c)

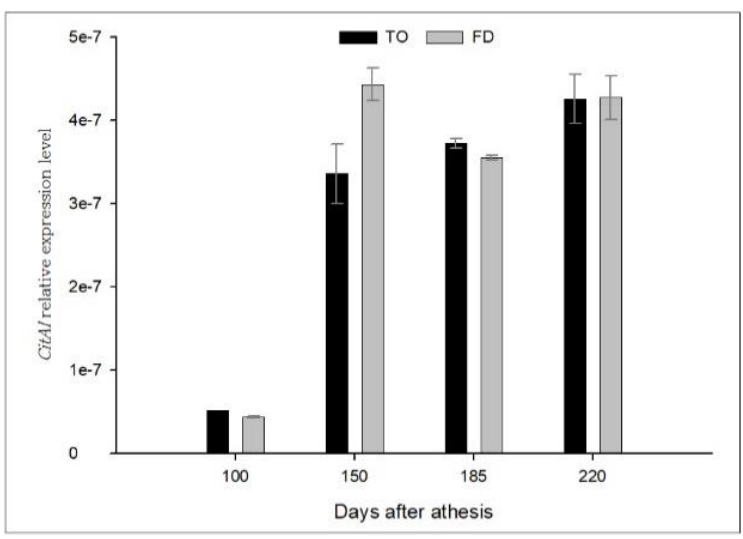

(e)

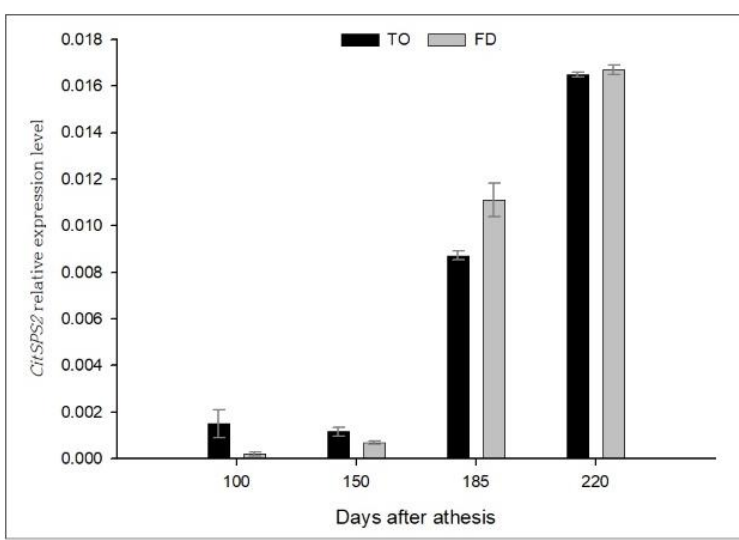

(b)

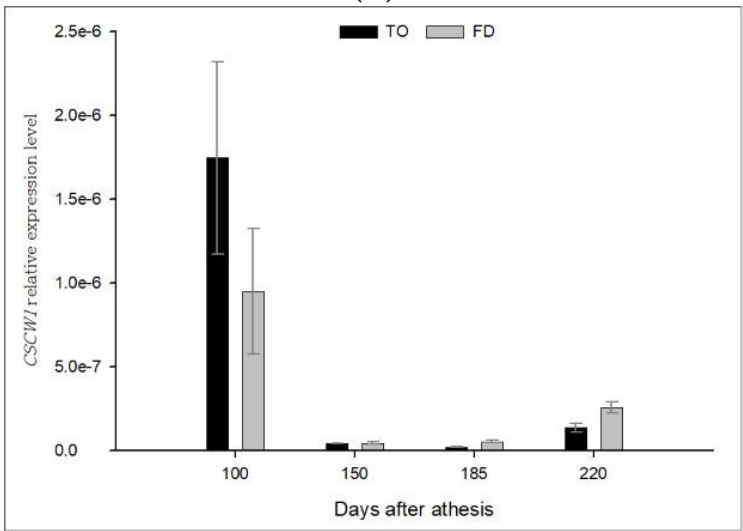

(d)

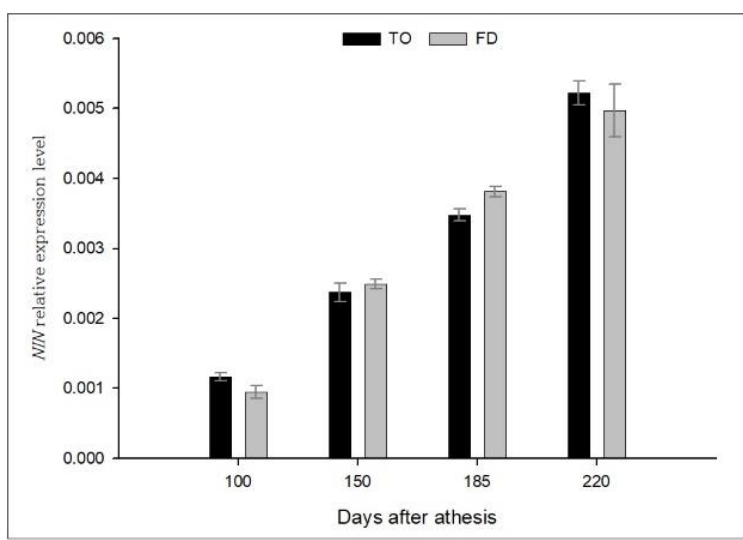

(f)

Figure 5. Real-time fluorescence quantitative PCR analysis for the relative expression of sucrose metabolic enzyme genes in the fruits of 'Minihyang' grafted on different rootstocks. (a) citrus sucrose phosphate synthase 1 (CitSPS1); (b) CitSPS2; (c) citrus sucrose synthase (CitSUS); (d) Citrus sinensis cell wall invertase (CSCW1); (e) citrus acid invertase (CitAI); (f) neutral invertase (NIN).

\section{Conclusions}

FD rootstock affected tree growth to be less vigorous and fruit quality enhanced with high SSC in 'Minihyang' mandarin compared to TO rootstock. The high SSC mainly correspond to increased sucrose content, which was attributed to enzyme activities related to sucrose unloading potential. However, the related gene expression was not entirely associated with sugar content and enzyme activities. Therefore, future studies, including post-transcriptional modification and the other primary metabolism, are invoked. 


\begin{abstract}
Author Contributions: Conceptualization, S.H.Y. and K.J.S.; methodology, H.R.H., E.U.O., S.G.H. and K.J.S.; formal analysis, H.R.H., E.U.O., H.B.K. and K.J.S.; investigation, H.R.H. and E.U.O.; resources, S.G.H. and S.H.Y.; data curation, H.R.H. and E.U.O.; writing-original draft preparation, H.R.H. and K.J.S.; writing-review and editing, H.B.K. and K.J.S.; funding acquisition, K.J.S. All authors have read and agreed to the published version of the manuscript.
\end{abstract}

Funding: This research was funded by Korea Institute of Planning and Evaluation for Technology in Food, Agriculture and Forestry (IPET) of Golden Seed Project, Grant Number 213007-05-5-SBQ10.

Institutional Review Board Statement: Not applicable.

Informed Consent Statement: Not applicable.

Data Availability Statement: All data generated or analyzed during this study are included in this published article.

Acknowledgments: We are highly thankful to the Citrus Research Institute (Jeju, Korea) for providing 'Minihyang' mandarin.

Conflicts of Interest: The authors declare no conflict of interest.

\title{
References
}

1. Sadka, A.; Shlizerman, L.; Kamara, I.; Blumwald, E. Primary metabolism in citrus fruit as affected by its unique structure. Front. Plant Sci. 2019, 10, 1167. [CrossRef] [PubMed]

2. KOSIS. Download Data from the KOSIS Database of the Korean Statistical Information Service. Available online: https://kosis.kr/ (accessed on 17 November 2021).

3. Castle, W.S. Rootstock as a fruit quality factor in citrus and deciduous tree crops. N. Z. J. Crop Hortic. 1995, 23, 383-394. [CrossRef]

4. Zhou, G.F.; Liu, Y.Z.; Sheng, O.; Wei, Q.J.; Yang, C.Q.; Peng, S.A. Transcription profiles of boron-deficiency-responsive genes in citrus rootstock root by suppression subtractive hybridization and cDNA microarray. Front. Plant Sci. 2015, 5, 795. [CrossRef] [PubMed]

5. Wu, X.; Riaz, M.; Yan, L.; Du, C.; Liu, Y.; Jiang, C. Boron deficiency in trifoliate orange induces changes in pectin composition and architecture of components in root cell walls. Front. Plant Sci. 2017, 8, 1882. [CrossRef]

6. Mademba-Sy, F.; Lemerre-Desprez, Z.; Lebegin, S. Use of Flying Dragon trifoliate orange as dwarfing rootstock for citrus under tropical climatic conditions. Hortic. Sci. 2012, 47, 11-17. [CrossRef]

7. Dong, T.; Xiong, B.; Huang, S.; Liao, L.; Qiu, X.; Sun, G.; He, Y.; Duan, C.; Wang, X.; Zhang, X.; et al. Investigation of the cause of reduced sugar content in Kiyomi tangor fruit of Ziyang xiangcheng (Citrus junos Sieb. ex Tanaka) rootstock. Sci. Rep. 2019, 9, 19263. [CrossRef]

8. Noda, K.; Okuda, H.; Kihara, T.; Iwagaki, I.; Kawase, K. Effects of rootstocks on tree growth and fruit quality in very early ripening satsuma mandarin 'Yamakawa'. J. Jpn. Soc. Hortic. Sci. 2001, 70, 78-82. [CrossRef]

9. Lin, Q.; Wang, C.; Dong, W.; Jiang, Q.; Wang, D.; Li, S.; Chen, M.; Liu, C.; Sun, C.; Chen, K. Transcriptome and metabolome analyses of sugar and organic acid metabolism in Ponkan (Citrus reticulata) fruit during fruit maturation. Gene 2012, 554, 64-74. [CrossRef]

10. Cardini, C.E.; Leloir, L.F.; Chiriboga, J. The biosynthesis of sucrose. J. Biol. Chem. 1995, 214, 149-155. [CrossRef]

11. Stein, O.; Granot, D. An overview of sucrose synthases in plants. Front. Plant Sci. 2019, 10, 95. [CrossRef]

12. Zhang, X.M.; Wang, W.; Du, L.Q.; Xie, J.H.; Yao, Y.L.; Sun, G.M. Expression patterns, activities and carbohydrate-metabolizing regulation of sucrose phosphate synthase, sucrose synthase and neutral invertase in pineapple fruit during development and ripening. Int. J. Mol. Sci. 2012, 13, 9460-9477. [CrossRef]

13. Kubo, T.; Hohjo, I.; Hiratsuka, S. Sucrose accumulation and its related enzyme activities in the juice sacs of satsuma mandarin fruit from trees with different crop loads. Sci. Hortic. 2001, 91, 215-225. [CrossRef]

14. Song, K.J.; Echeverria, E.; Lee, H.S. Distribution of Sugars and Related Enzymes in the Stem and Blossom Halves of 'Valencia' Oranges. J. Am. Soc. Hortic. Sci. 1998, 123, 416-420. [CrossRef]

15. Van Handel, E. Direct microdetermination of sucrose. Anal. Biochem. 1968, 22, 280-283. [CrossRef]

16. Brandford, M.M. A rapid and sensitive method for the quantitation of microgram quantities of protein utilizing the principle of protein-dye binding. Anal. Biochem. 1976, 72, 248-254. [CrossRef]

17. Cantuarias-Avilés, T.; Mourão Filho, F.D.A.A.; Stuchi, E.S.; da Silva, S.R.; Espinoza-Núñez, E.; Neto, H.B. Rootstocks for high fruit yield and quality of 'Tahiti' lime under rain-fed conditions. Sci. Hortic. 2012, 142, 105-111. [CrossRef]

18. Andersen, P.C.; Brodbeck, B.V. Yield, tree size, and fruit quality of mature "owari" and "brown select" satsuma on Poncirus trifoliata "Rubidoux" and 'Flying Dragon' Rootstocks in North Florida. HortScience 2015, 50, 1650-1653. [CrossRef]

19. Domingues, A.R.; Marcolini, C.D.M.; Goncalves, C.H.S.; Resende, J.T.V.; Roberto, S.R.; Carlos, E.F. Rootstocks genotypes impact on tree development and industrial properties of 'Valencia' sweet orange juice. Horticulturae 2021, 7, 141. [CrossRef]

20. Marsh, K.B.; Richardson, A.C.; Macrae, E.A. Early-and mid-season temperature effects on the growth and composition of satsuma mandarins. J. Hortic. Sci. Biotechnol. 1999, 74, 443-451. [CrossRef] 
21. Zhang, J.; Ritenour, M.A. Sugar composition analysis of commercial citrus juice products. Proc. Fla. State Hortic. Soc. 2016, 129, 178-180.

22. Moon, Y.E.; Kang, S.B.; Han, S.G.; Kim, Y.H.; Choi, Y.H.; Koh, S.C.; Oh, S.J. Effects of elevated spring temperatures on the growth and fruit quality of the Mandarin hybrid 'Shiranuhi'. Kor. J. Hortic. Sci. Technol. 2015, 33, 459-469.

23. Bowman, K.D.; McCollum, G. Five new citrus rootstocks with improved tolerance to huanglongbing. Hortic. Sci. 2015, 50, $1731-1734$.

24. Liu, Y.Z.; Liu, Q.; Xiong, J.J.; Deng, X.X. Difference of a citrus late-maturing mutant (Citrus sinensis) from its parental line in sugar and acid metabolism at the fruit ripening stage. Sci. China Ser. C. 2007, 50, 511-517. [CrossRef] [PubMed]

25. Kim, S.B.; Oh, E.U.; Park, J.H.; Yun, S.H.; Oh, H.W.; Kang, J.H.; Koh, S.W.; Oh, H.J.; Song, K.J. Fruit growth, sugar, and acid characteristic in leafy and leafless fruits of Satsuma mandarin. Kor. J. Hortic. Sci. Technol. 2012, 30, $642-649$.

26. Raddatz-Mota, D.; Franco-Mora, O.; Mendoza-Espinoza, J.A.; Rodríguez-Verástegui, L.L.; de León-Sánchez, F.D.; Rivera-Cabrera, F. Effect of different rootstocks on Persian lime (Citrus latifolia T.) postharvest quality. Sci. Hortic. 2019, 257, 108716. [CrossRef]

27. Albrigo, L.G.; Stelinski, L.L.; Timmer, L.W. Citrus; CABI: Oxfordshire, UK, 2019.

28. Reese, R.I.; Loo, R.C.J. Effect of $\mathrm{N}$ and $\mathrm{K}$ fertilization on internal and external fruit quality of three major Florida orange cultivars. J. Am. Soc. Hortic. Sci. 1975, 100, 425-428.

29. Liao, L.; Dong, T.; Qiu, X.; Rong, Y.; Qang, Z.; Zhu, J. Nitrogen nutrition is a key modulator of the sugar and organic acid content in citrus fruit. PLoS ONE 2019, 14, e0223356. [CrossRef]

30. Komatsu, A.; Moriguchi, T.; Koyama, K.; Omura, M.; Akihama, T. Analysis of sucrose synthase genes in citrus suggests different roles and phylogenetic relationships. J. Exp. Bot. 2002, 53, 61-71. [CrossRef]

31. Barry, G.H.; Castle, W.S.; Davies, F.S. Rootstocks and plant water relations affect sugar accumulation of citrus fruit via osmotic adjustment. J. Am. Soc. Hortic. Sci. 2014, 129, 881-889. [CrossRef]

32. Hockema, B.R.; Etxeberria, E. Metabolic contributors to drought-enhanced accumulation of sugars and acids in orange. J. Am. Soc. Hortic. Sci. 2001, 126, 599-605. [CrossRef]

33. Islam, M.Z.; Hu, X.M.; Jin, L.F.; Liu, Y.Z.; Peng, S.A. Genome-wide identification and expression profile analysis of citrus sucrose synthase genes: Investigation of possible roles in the regulation of sugar accumulation. PLoS ONE 2014, 9, e113623. [CrossRef] [PubMed]

34. Komatsu, A.; Takanokura, Y.; Akihama, T.; Omura, M. Cloning and molecular analysis of cDNAs encoding three sucrose phosphate synthase isoforms from a citrus fruit (Citrus unshiu Marc.). Mol. Gen. Genet. 1996, 252, 346-351. [CrossRef] [PubMed] 